\title{
UPAYA MENINGKATKAN KEMAMPUAN PEMAHAMAN KONSEP MATEMATIS SISWA PADA MATERI BENTUK ALJABAR MELALUI PENDEKATAN CONTEXTUAL TEACHING AND LEARNING BERBANTU ALAT PERAGA DI KELAS VII-7 SMP NEGERI 18 TANGERANG SELATAN
}

\author{
Rizqi Kurniai"), Slamet Soro' ${ }^{2)}$, Nurafni ${ }^{3)}$ \\ ${ }^{1)}$ Universitas Muhammadiyah Prof. DR. HAMKA, Jl. Tanah Merdeka No 20, Jakarta \\ Timur; rizqikurnia03@gmail.com \\ 2) Universitas Muhammadiyah Prof. DR. HAMKA, Jl. Tanah Merdeka No 20, Jakarta \\ Timur; slamet.soro@yahoo.co.id \\ 3) Universitas Muhammadiyah Prof. DR. HAMKA, Jl. Tanah Merdeka No 20, Jakarta \\ Timur; nurafni.matematika@uhamka.ac.id
}

\begin{abstract}
This research was conducted at 18 junior high schools South Tangerang city year of study 2019/2020 in August-October 2019. The subject of this research is a student in VII-7 grade at 18 junior High School south of Tangerang city, there are 38 students. The learning method used in this research is action research with the model of Kurt Lewin, there are four stages of planning, implementation, observation and reflection consisting of two cycles. Based on the results of this research, the average value of students ability to understand the mathematical concept before action is 45.48 with the percentage of achievement KKM 15.79\%. After an action acquired the average value of students ability to understand the mathematical concept on the first cycle is 66.91 with a percentage of achievement KKM 52.63\% and it doesn't reach the target yet. After making repairs by improving the activity of students during the process of learning activities, then obtain an average of students ability to understand a mathematical concept in the second cycle is 76.31 with a percentage of Achievement $81.58 \%$. The results concluded that through a learning approach Contextual Teaching and Learning can improve the student's ability to understand the mathematical concept in class VII-7 at 18 junior high schools south of Tangerang city.
\end{abstract}

Keywords. The ability to understand mathematical concepts of students, Contextual teaching and learning approach, Props

\section{Pendahuluan}

Matematika merupakan salah satu ilmu dasar yang harus dikuasai setiap manusia, terutama oleh siswa di sekolah. Maka tidak heran jika pelajaran matematika sudah diajarkan mulai dari taman kanak-kanak hingga

Euclid, p-ISSN 2355-1712, e-ISSN 2541-4453, Vol. 7, No. 1, pp. 1- 76 CLembaga Penelitian Universitas Swadaya Gunung Jati (UGJ), Cirebon. 
perguruan tinggi. Matematika adalah salah satu ilmu pengetahuan yang dominan dengan perhitungan dan rumus-rumus. Banyak siswa yang beranggapan bahwa matematika merupakan mata pelajaran yang memiliki berbagai macam rumus yang harus dihafalkan.

Sejalan dengan yang dinyatakan oleh Syaiful bahwa salah satu penyebab kurangnya kemampuan pemahaman konsep matematis siswa adalah kebiasaan siswa yang belajar dengan cara menghafal (Budiarti, Purwanto, \& Hendriana, 2019: 17). Dalam kegiatan pembelajaran di dalam kelas, siswa hanya diarahkan pada kemampuan cara menggunakan rumus, menghafal rumus, dan mengerjakan soal tanpa didorong untuk mengembangkan kemampuan pemahaman konsepnya. Hal ini merupakan salah satu penyebab rendahnya kemampuan pemahaman konsep matematis siswa khususnya pada mata pelajaran matematika.

Hal tersebut dapat dilihat dari nilai rata-rata uji prasiklus atau nilai rata-rata pada materi bilangan di kelas VII-7 SMP Negeri 18 Tangerang Selatan sebelum diadakannya tindakan yaitu sebesar 45,48. SMP Negeri 18 Tangerang selatan telah menetapkan KKM siswa, yaitu 75. Sehingga dari data awal yang diperoleh bahwa terdapat 6 siswa atau sekitar 15,79\% siswa yang telah mencapai KKM, sedangkan sisanya 32 siswa atau sekitar 84,21\% siswa masih belum mencapai KKM. Hal ini menunjukkan bahwa kemampuan pemahaman konsep matematis siswa di kelas VII-7 SMP Negeri 18 Tangerang Selatan masih rendah.

Kurangnya pemahaman konsep matematis siswa juga terlihat pada hasil penelitian Rusyda dan Sari (2017: 153) bahwa hanya 2 kelas yang memiliki jumlah siswa yang tuntas lebih tinggi daripada siswa yang tidak tuntas dalam materi bilangan bulat yaitu kelas VII-3 dan VII-6. Keenam kelas lainnya memiliki jumlah siswa yang tidak tuntas lebih tinggi daripada siswa yang tuntas. Pada penelitian tersebut dijelaskan pula bahwa siswa tidak mampu mengemukakan alasan-alasan dari suatu konsep serta siswa tidak mampu menghubungkan benda nyata, gambar maupun soal cerita ke dalam ide matematika. Hal ini disebabkan karenakan rendahnya kemampuan pemahaman konsep matematis siswa. 
Berdasarkan pemaparan di atas maka untuk meningkatkan kemampuan pemahaman konsep matematis siswa diperlukan pendekatan pembelajaran salah satunya adalah pendekatan Contextual Teaching and Learning, karena pendekatan pembelajaran ini merupakan salah satu pendekatan pembelajaran yang tepat untuk meningkatkan pemahaman konsep matematis siswa. Hal ini telah dijabarkan atau dibuktikan oleh penelitian yang dilakukan oleh Fatmawati, Subarjah, dan Isrok'atun (2016: 1079) bahwa: "Pembelajaran menggunakan CTL terbukti mampu dalam meningkatkan kemampuan pemahaman matematis siswa di kelas eksperimen. Hal ini dapat dibuktikan berdasarkan n-gain yang diperoleh dari rata-rata nilai hasil postes menggunakan CTL, secara menyakinkan mengalami peningkatan pada saat sebelum dan sesudah pembelajaran"

Untuk menunjang kemampuan siswa dalam memahami konsep matematis maka peneliti menggunakan alat peraga matematika yang berkaitan dengan materi bentuk aljabar yaitu kotak aljabar, keping aljabar dan benda-benda yang ada di kehidupan sehari-hari. Fachrurazi (2018) mengungkapkan bahwa alat peraga matematika adalah suatu benda konkrit yang dapat dimanipulasi, guna menjembatani abstraksi matematika dan pencapaian kemampuan matematika tingkat tinggi. Sedangkan benda manipulatif adalah alat bantu untuk menyampaikan atau menjelaskan konsep matematika dengan menggunaan benda konkrit tertentu yang akan membantu siswa dalam merepresentasikan sebuah konsep dengan benar (Kania, 2018).

Berdasarkan latar belakang masalah di atas maka peneliti akan melakukan penelitian dengan judul "Upaya meningkatkan kemampuan pemahaman konsep matematis siswa pada materi bentuk aljabar melalui pendekatan Contextual Teaching and Learning berbantu alat peraga di kelas VII-7 SMP Negeri 18 Tangerang Selatan"

\section{Metodologi Penelitian}

\subsection{Prosedur Penelitian}

Pada penelitian ini peneliti mengacu pada Metode Penelitian Tindakan Kelas dari Kurt lewin. Kurt Lewin (Dalam Pujiati, Nyata, \& Taniredja, 2013: 23) mengungkapkan bahwa konsep inti PTK terdiri dari empat langkah yaitu 
perencanaan (planning), aksi atau tindakan (action), observasi (observing), dan refleksi (reflecting).

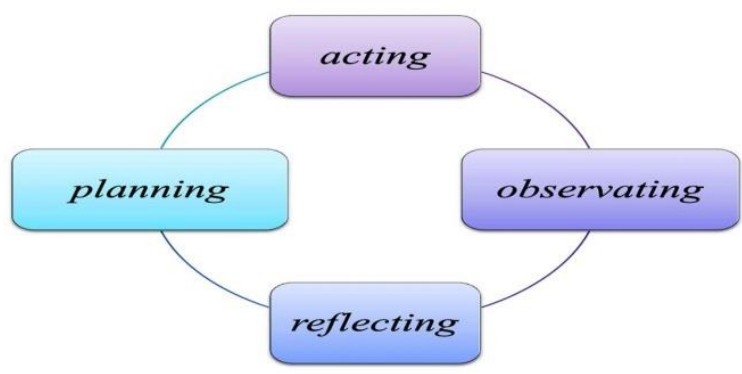

Gambar 3.2

PTK Model Kurt Lewin

Apabila hasil akhir dari tahapan refleksi belum memenuhi indikator kemampuan pemahaman konsep matematis siswa maka peneliti harus kembali lagi kepada tahap perencanaan atau melanjutkan tahap berikutnya, tetapi jika hasil akhir dari tahapan refleksi sudah memenuhi indikator kemampuan pemahaman konsep matematis maka penelitian selesai atau peneliti tidak perlu melanjutkan siklus berikutnya.

\subsection{Subjek Penelitian}

Pada penelitian ini subjek penelitian tindakan kelas adalah siswa kelas VII-7 tahun pelajaran 2019/2020 dengan jumlah 38 siswa yang terdiri dari 18 lakilaki dan 20 perempuan. Pihak yang terkait dalam penelitian ini adalah guru mata pelajaran matematika Ibu Titta Nuar Afriati, S.Pd yang bertindak sebagai kolaborator dan yang bertindak sebagai observer yaitu Ibu Yuza Devi Zen, S.Pd. Karakteristik yang ingin diteliti adalah Kemampuan Pemahaman Konsep Matematis siswa dengan pendekatan Contextual Teaching and Learning (CTL) berbantu alat peraga manipulatif yang digunakan peneliti dalam pembelajaran di kelas VII-7.

\section{Hasil Pembahasan}

Hasil pembelajaran dengan menggunakan pendekatan Contextual Teaching and Learning telah dilaksanakan dengan baik. Pembelajaran matematika dengan menggunakan pendekatan Contextual Teaching and Learning terbukti meningkatkan kemampuan pemahaman konsep matematis siswa kelas VII-7 SMP Negeri 18 Tangerang Selatan. Rincian mengenai peningkatan 
kemampuan pemahaman konsep matematis siswa dapat dilihat dalam tabel berikut ini:

Tabel 4.1

Data Nilai Rata-rata dan Persentase Pencapaian

\begin{tabular}{|c|c|c|c|c|}
\hline \multirow{2}{*}{ No. } & Kriteria & \multicolumn{3}{|c|}{ Persentase } \\
\cline { 3 - 5 } & & Pra Siklus & Siklus I & Siklus II \\
\hline 1 & Nilai Rata-rata kelas & 45,48 & 66,91 & 76,31 \\
\hline 2 & Sudah mencapai KKM & $15,79 \%$ & $52,63 \%$ & $81,58 \%$ \\
\hline
\end{tabular}

Dari data di atas, maka dapat disajikan dalam diagram sebagai berikut:

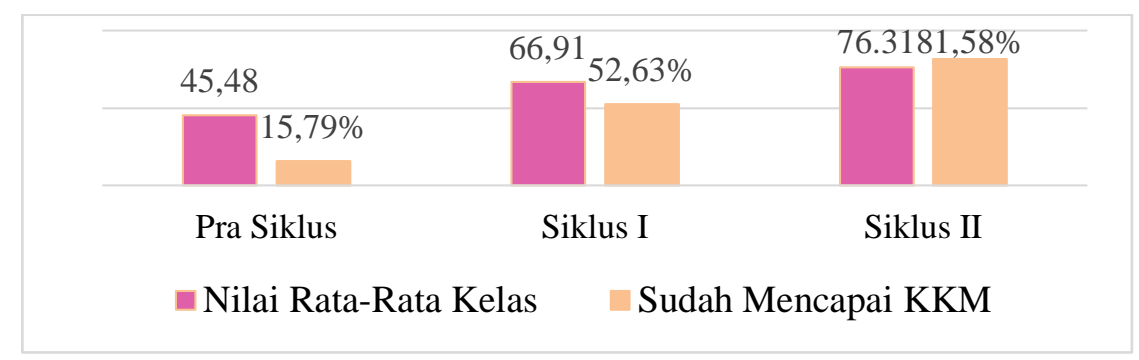

Gambar 4.1

\section{Diagram Persentase data Nilai Rata-Rata Pencapaian KKM}

Berdasarkan gambar di tersebut dapat dijelaskan bahwa kemampuan pemahaman konsep matematis siswa mengalami peningkatan dari test pra siklus yang memperoleh nilai rata-rata kelas 45,48 dengan persentase siswa yang mencapai kriteria ketuntasan minimal (KKM) 15,79\% . Setelah dilakukannya tindakan pembelajaran dengan menggunakan pendekatan pembelajaran Contextual Teaching and Learning berbantu alat peraga pada siklus I, nilai rata-rata kelas menjadi 66,91 dan persentase pencapaian siswa yang mencapai KKM meningkat menjadi 52,63\%, kemudian terlihat peningkatan kemampuan pemahaman konsep matematis siswa pada siklus II.

Pada siklus II memperoleh nilai rata-rata kelas sebesar 76,31 dan persentase pencapaian KKM sebesar 81,58\%. Berdasarkan data tersebut, maka dapat diketahui bahwa pembelajaran menggunakan pendekatan Contextual Teaching and Learning berbantu alat peraga matematika dapat 
meningkatkan kemampuan pemahaman konsep matematis siswa di kelas VII-7 SMP Negeri 18 Tangerang Selatan.

\section{Simpulan}

Bedasarkan penelitian tindakan kelas (PTK) yang dilakukan di SMP Negeri 18 Tangerang Selatan dalam 2 siklus dengan 3 pertemuan pembelajaran dan 1 pertemuan tes evaluasi pada siklus pertama, dan 3 pertemuan pembelajaran dan 1 pertemuan tes evaluasi pada siklus kedua, dengan total 8 pertemuan, maka dapat disimpulkan bahwa pendekatan pembelajaran Contextua Teaching and Learning berbantu alat peraga manipulatif dapat meningkatkan kemampuan pemahaman konsep matematis siswa pada materi bentuk aljabar di SMP Negeri 18 Tangerang Selatan.

Adanya peningkatan dapat dilihat dari hasil data yang didapatkan sebelum maupun sesudah dilakukan tindakan pada setiap siklusnya. Peningkatan kemampuan pemahaman konsep matematis siswa dapat dilihat dari nilai rata-rata kelas. Nilai rata-rata siswa pada data awal yaitu data uji prasiklus 45,48 dengan siswa yang mencapai KKM memperoleh persentase 15,79\% lalu peneliti melakukan tindakan pada siklus I rata-rata nilai matematika kelas VII-7 yang diperoleh adalah 66,91 dan persentase KKM yang diperoleh $52,63 \%$. Serta pada siklus II nilai rata-rata siswa yang diperoleh adalah 76,22 dengan persentase yang mencapai KKM adalah 81,58\%. Hal ini menunjukkan bahwa pendekatan pembelajaran Contextual Teaching and Learning berbantu alat peraga manipulatif dapat meningkatkan hasil belajar yang berindikator kemampuan pemahaman konsep matematis siswa kelas VII-7 di SMP Negeri 18 Tangerang Selatan dari sebelum tindakan, siklus I dan siklus II.

\section{Daftar Pustaka}

Astuti, T. P., Masykur, R., \& Pratiwi, D. D. (2018). Pengaruh model pembelajaran tandur terhadap kemampuan pemahaman konsep dan penalaran matematis peserta didik. Jurnal Pendidikan Matematika FKIP Univ. Muhammadiyah Metro , 7 (2), 203.

Budiarti, C. D., Purwanto, S. E., \& Hendriana, B. (2019). Kontribusi Model Pembelajaran M-Apos Terhadap Kemampuan Pemahaman Konsep Matematis Siswa. KALAMATIKA Jurnal Pendidikan Matematika, 4(1), 17. 
Fachrurazi. (2018). Benda manipulatif dari sandal jepit dan pelepah rumbia untuk pemahaman konsep aljabar kelas VIII SMP. Jurnal pesona dasar , 6 (1), 2.

Fatmawati, F. F., Subarjah, H., \& Isrok'atun. (2016). Contextual Teaching and Learning untuk meningkatkan kemampuan pemahaman matematis siswa. Jurnal Pena Ilmiah , 1 (1), 1079.

Hasratuddin. (2014). Pembelajaran Matematika Sekarang dan yang akan Datang Berbasis Karakter. Jurnal Didaktik Matematika , 1 (2), 30.

Indriani, R., Puspita, A. M. I., Ninawati, M., Handayani, H., \& Agusfianuddin. (2019). Contextual Teaching and Learning Untuk Meningkatkan Kemampuan Pemahaman Konsep Pecahan. KALAMATIKA Jurnal Pendidikan Matematika, 4 (1), 111.

Kania, N. (2018). Alat peraga untuk memahami konsep pecahan. Jurnal THEOREMS (The Original Research Of Mathematics) , 2 (2), 2.

Lestari, K. E., \& Yudhanegara, M. R. (2017). Penelitian Pendidikan Matematika. Bandung: PT Refika Aditama.

Mawaddah, S., \& Ratih, M. (2016). Kemampuan pemahaman konsep matematis siswa SMP dalam pembelajaran menggunakan model penemuan terbimbing (Discovery Learning). Jurnal Pendidikan Matematika , 4 (1), 77.

Pujiati, I., Nyata, \& Taniredja, T. (2013). Penelitian Tindakan Kelas untuk mengembangkan profesi guru praktik, praktis, dan mudah. Bandung: Alfabeta, cv.

Rusyda, N. A., \& Sari, D. S. (2017). Pengaruh penerapan model Contextual Teaching and Learning terhadap kemampuan pemahaman konsep matematis siswa SMP pada materi Garis dan Sudut. Jurnal Nasional Pendidikan Matematika (JNPM), 1(1), 153 .

Sabroni, D. (2017). Pengaruh model pembelajaran Contextual Teaching and Learning (CTL) terhadap kemampuan komunikasi matematis siswa. Seminar Nasional Matematika dan Pendidikan Matematika , 1 (1), 58.

Sagala, S. (2014). Konsep dan Makna Pembelajaran. Bandung: Alfabeta

Santoso, E. (2017). Penggunaan model pembelajaran kontekstual untuk meningkatkan kemampuan pemahaman matematika siswa sekolah dasar. Jurnal Cakrawala Pendas , 3 (1).

Suhartati. (2012). Representasi Geometri dari Bentuk Aljabar. Jurnal Peluang,1 (1), 52.

Wakijo, \& Suprihatin, S. (2016). Implementasi Pendekatan Contextual Teaching and Learning (CTL) Terhadap Kemampuan Berpikir Kritis Siswa. Jurnal Promosi , 4 (2), 45. 